\title{
Enhancing Phrasal Verb Learning: A Quasi-experimental Study of Different Approaches
}

\section{Brian J. Birdsell \\ Hirosaki University}

\section{Reference Data}

Birdsell, B. J. (2021). Enhancing phrasal verb learning: A quasi-experimental study of different approaches. In P. Clements, R. Derrah, \& P. Ferguson (Eds.), Communities of teachers \& learners. JALT. https://doi.org/10.37546/JALTPCP2020-30

Phrasal verbs (PVS) are notoriously difficult for language learners since they are numerous in number, highly polysemous, as well as metaphorical, and the meaning is often opaque. Over the past two decades, researchers have shown the benefits of using a cognitive linguistic approach to teaching them. Expanding this line of research, a quasi-experimental study was conducted to investigate the effects of an embodied approach to teaching phrasal verbs. An embodied learning approach focuses on movement, gesture, and enactment as a way to facilitate language learning. Student participants $(N=80)$ were divided into 3 groups; an L1 translation approach group, a cognitive approach group, and an embodied learning approach group. They took pre- and post$\mathrm{PV}$ tests and learned $29 \mathrm{PVS}$ in 2 teaching interventions. All students significantly improved their scores, but those in the cognitive and embodied learning groups significantly outperformed the L1 translation group.

句動詞 (phrasal verbs) は、数が多く、多義性が高く、比喻的であり、意味が不透明であることが多いため、英語学習者にと って難しいことでよく知られている。過去数十年の研究で、句動詞教育には認知言語学的アプロ一チが有効であることが示 って難しいてとでよく知られている。過去数十年の研究で、句動詞教育には認知言語学的アフローチが有効であることが示 されたが。本研究はそれを発展させつつ、からだで学ぶアプローチ(身体運動、ジェスチャー、実演を用いた学習促進法)の 効果を検証するための隻実験的研究を行つた。本研究では学生参加者 $(\mathrm{N}=80)$ を、第一言語への翻訳アプローチ、認知的ア プローチ、からだで学ぶアプローチの3つのブループに分けた。学生参加者たちは、事前及び事後に句動詞テストを受け、2 回の教育的介在において29個の句動詞を学習した。結果は、すべての学生かスコアを大きく伸はしたか、なかでも認知的学 習クループとからたで学ぶグループの学生たちは、第一言語への翻訳グループを大きく上回る学習成果を示したことを本研 究で明らかにした hrasal verbs (PVs) are notoriously difficult for language learners for several different reasons. First, they are often said to be semantically opaque. For instance, why do lovers break up and not break down? Or, why do you take up a new interest but take on a new responsibility? In addition to lacking transparency, they are also highly polysemous. Some estimates suggest that there are, on average, 5.6 different meanings for each of the 100 most frequent PVs (Gardner \& Davies, 2007). Yet, their usefulness cannot be understated since they are ubiquitous in the English language (Celce-Murcia \& LarsenFreeman, 1999), more specifically, it is suggested through research that there is one PV in every 150 words of English (Gardner \& Davies, 2007). Despite their wide use and usefulness, they are often avoided by L2 learners (Liao \& Fukuya, 2004; Siyanova \& Schmitt, 2007). Thus, researchers and instructors have persistently looked for more effective ways to teach them. Recent trends over the past two decades have investigated the benefits of teaching PVs using a cognitive linguistic approach, which typically focuses on the particle for meaning or a diagram that highlights the image schema that motivates the PV (see Rudzka-Ostyn, 2003; Tyler \& Evans, 2003). The study presented here extends this previous research by including another teaching approach based on the theoretical findings in embodied cognition. Embodied cognition has been gaining interest in the field of education (see Skulmowski \& Rey, 2018) as well as foreign and second language learning (see Atkinson, 2010; Birdsell, 2015). An embodied learning approach to the teaching of PVs emphasizes coupling the target language with congruent action such as enactment, pantomimes, and gestures, and doing this facilitates the learning.

In this paper, the theoretical background for using a cognitive linguistic approach to teaching PVs and studies that have shown beneficial effects of this approach will be reviewed first. Then, embodied cognition will be briefly discussed and an embodied learning approach for teaching PVs will be proposed. Finally, a quasi-experimental study that investigated the effects of using a cognitive approach, an embodied learning approach, and a more traditional L1 translation approach will be presented. 
JALT2020

COMMUNITIES OF
TEACHERS \& LEARNERS

\section{Literature Review}

A Cognitive Linguistic Approach to Teaching Phrasal Verbs

Since the 2000s, many researchers have begun to experiment with using a cognitive linguistics approach to teaching PVs (Rudzka-Ostyn, 2003; Tyler \& Evans, 2003). Such an approach focuses on raising learners' awareness of the cognitive motivations underlying them. Under a cognitive linguistic framework, PVs, instead of being viewed as random and arbitrary, are viewed as having some degree of systematicity, and this motivates the particle used in the PV (Lakoff, 1987). For example, the PVs pay off and call off are motivated by the orientational metaphor, OFF IS CANCELLING/STOPPING. Thus, such an approach contends that if language learners acquire the motivations underlying these PVs, they will learn, remember, and use them more easily (Csábi, 2004). Consequently, one cognitive linguistic approach to teaching PVs is to organize them based on an orientational metaphor, as a way to both highlight the fact that PVs are not arbitrary and to raise the learners' awareness of the cognitive structure that motivates them. As for research that supports this approach, Yasuda (2010) did a study with 115 Japanese university students to investigate if enhancing learners' awareness of the embedded orientational metaphor would facilitate the acquisition of PVs (e.g., break down, burst into, call off). She divided her participants into two random groups, a control group that learned the English PVs with Japanese translation and the experimental group that used a cognitive approach. Results from her study show both groups of students improved their scores on items that they had learned (or were exposed to), but on items that were new to them (or they were not exposed to), the experimental group outperformed the control group. She interpreted these results as suggesting those who learned the motivations of the PVs were then able to apply these to new and unknown ones. In another large study involving 8-week teaching interventions along with pre-, post-, and delayed posttest, Condon (2008) found that explicit knowledge of the cognitive motivations underlying the PVs helps retention, as indicated from higher scores on the delayed posttest. In summary, there is good evidence that a cognitive approach to teaching PVs is beneficial, as it provides transparency and semantic organization to the PVs.

However, from trying to use such an approach in a classroom, the learners were often confused with the jargon used to describe these orientational metaphors. Therefore, for this study a second way to organize the PVs using a cognitive linguistic approach was considered, which relies on the use of diagrams that focus on the image schema. Image schemas are simple structures based on the body's movement through space and reoccurring interaction with the environment (Johnson, 1987; Lakoff, 1987). These may include such structures as SOURCE-PATH-GOAL, BALANCE, and BOUNDED
REGIONS. To illustrate this, consider the following diagram (see Figure 1). In this diagram, the black square is in a bounded space and now has left it. What are some bounded spaces? They may be physical spaces like a club or a hotel or abstract bounded spaces like when you shake hands with someone and sign a contract. This image schema motivates such metaphors as the following; He got kicked out of the club; He checked out of the hotel, and; He tried to get out of the contract.

Figure 1

Example of a Diagram for the Image Schema BOUNDED REGIONS

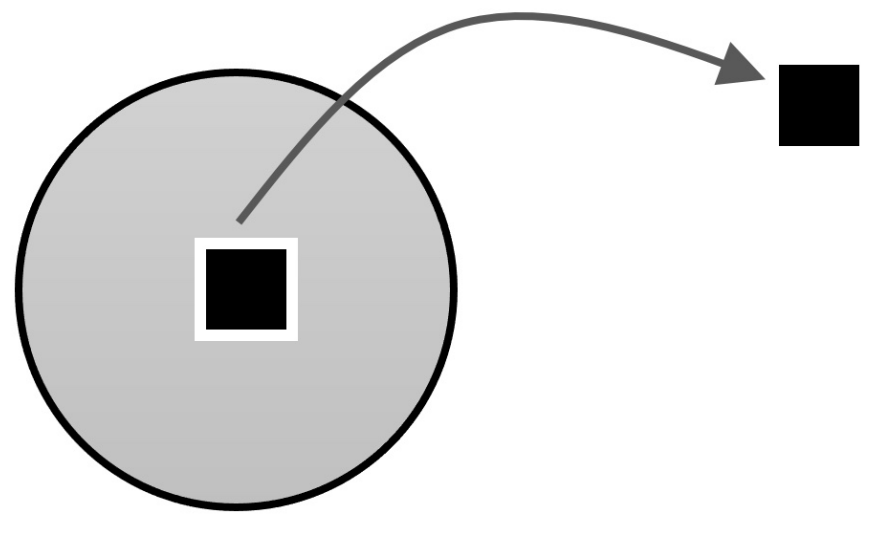

The idea of using visual imagery in the language classroom has a long history as material that facilitates and enhances language learning (Jahangard 2007; Omaggio, 1979). Using imagery within a cognitive-linguistic framework has been done with

PVs. For example, White (2012) had students express the meanings of the PVs through drawings in order to make the meaning more personal, help with retention, and reflect on the metaphorical nature of many PVs. In short, combining ideas from cognitive linguistics with multimodal learning has the potential to facilitate the learning of PVs, as they provide visual cues to support meaning construction. Therefore, in this study, one experimental group learned PVs through a cognitive approach that used images to highlight the image schema of the PV. 
Embodied Cognition: Language, the Body, and Language Learning

Theories of embodied cognition cross the fields of cognitive science, psychology, linguistics, and $\mathrm{Al}$ and argue that cognition is shaped by embodied experiences (Gibbs, 2005). Instead of viewing cognition as disembodied and something that happens in the head, proponents of an embodied view of cognition describe it as a performative theory of mind and brain (Anderson, 2014) where "cognition exists to guide action" (Glenberg et al., 2013, p. 573). Therefore, there is a deep structural coupling of the body and language. This means that the content of our semantic memory is grounded in situations, perception (visual, auditory, olfactory, gustatory, tactile), action (movement), and introspection (mental states, emotion) (Barsalou, 2008; Gibbs, 2005). Both behavioral and neuroimaging research has provided compelling evidence to support this view. For example, researchers have shown that the neural sensorimotor systems are active during language processing (Buccino et al., 2001; Hauk et al., 2004; Sakreida et al., 2013), and thus "language makes direct use of the same brain structures used in perception and action" (Gallese \& Lakoff, 2005, p. 473). So, when one reads the word "kick," the same neural structure involved with the action (the "leg" area of the motor cortex) becomes active (Hauke et al., 2004), and when one reads a word like "garlic" or "lavender," the neural structure involved with olfaction becomes active, as compared to reading non-olfactory control words like "coat" (González et al., 2006) and this has been replicated with other sensory systems such as gustation (Barros-Loscertales et al., 2012). It is thus assumed that semantic knowledge reactivates experiential traces, which can be sensory, motor, emotional, or situational experiences and these simulations provide semantic content for words like "kick," "garlic," and "put on." Learning vocabulary comes from making associations with some referent in the world around us (an object: tree, book; or an action: run, cut up; or property: green, fast). The co-occurrence of language and action strengthens the link between the neural structure and linguistic concept (Vukovic \& Shtyrov, 2014) and thus, learning the word ("hand out") accompanied with congruent action (gesture, enactment, mime) will result in the word being more strongly encoded than learning it accompanied with linguistic information (definition or example sentence) only. However, the above research has primarily focused on concrete words or action-based verbs, and there is still considerable debate regarding abstract language (see Dove, 2011). Yet, others argue that metaphors work as a bridge to connect embodied experiences with abstract concepts (see Jamrozik et al., 2016). Take, for example, the PV back out of. This can literally refer to a car backing out of a garage and metaphorically to the abstract situation of an individual backing out of a contract or wedding engagement. The garage and similarly the contract are viewed as a form of containment, and the action involves the physical movement from this contained space outward to the point where one is no longer bound by this contained space.
Both of these situations can be enacted to reinforce the different senses of this PV (literal and abstract).

Moreover, theories of embodied cognition have been influencing the field of foreign language learning (see Atkinson, 2010; Birdsell, 2015) and have been proposed to have the potential for teaching PVs (see Birdsell, 2020). In one study with action-related verbs, Lindstromberg and Boers (2005) found when students enacted the meaning of a word, they outperformed a control group who saw it, listened to it, and then verbally explained it. Based on the results from their study, they concluded "enacting or miming a verb resulted in better retention than explaining it" (p. 249). In addition, there have been recent studies that have shown how gesture facilitates foreign language learning (Macedonia \& Klimesch, 2014; Macedonia \& Knösche, 2011; Morett, 2014), which similarly point out the benefits of coupling language to congruent action. In order to investigate whether "vocabulary learning can be helped by the physical enactment of vocabulary" (Holme, 2009, p. 44), three different teaching interventions were used in this study to teach a set of PVs; a linguistic approach, which used L1 translation support, a cognitive linguistic approach, which used images; and an embodied approach, where the learners watched actors enact and pantomime the meanings of the PVs.

\section{Participants}

\section{Method}

First-year students $(N=80$; female $=27)$ at a national university in Japan participated in this study. They were all in advanced English classes, as determined by a university placement test at the start of the year. They came from many different faculties (i.e., humanities, science \& technology, education), but most of the participants were from the school of medicine $(n=48)$. All students gave informed consent, were provided information about the purpose of the study, and after the completion of the study, were provided with results in a follow-up session. The classes were randomly assigned into 3 groups: the L1 translation group $(n=26)$; the cognitive image group $(n=26)$; and the enactment group $(n=28)$.

Research Questions

RQ1. Did learners' scores on the post-PV tests significantly improve from the pre-PV tests?

RQ2. Did learners' scores from one group significantly improve more than the other groups? 
JALT2020

COMMUNITIES OF
TEACHERS \& LEARNERS

\section{Material}

A pretest-posttest design was used for the purpose of comparing groups and measuring changes from the PV teaching interventions. A total of 29 PVs using nine verbs (break, back, cut, hand, hold, look, stand, take, turn) were used in this study. A list of 40 PVs was initially selected based on frequency in the language (Garnier \& Schmitt, 2015) and then the list was reduced to 29 during the recording of the enactment group videos. This reduction was mainly due to the difficulty of enacting the meaning of some PVs. The material consisted of a 50-item PV test that only contained PVs (29) that were taught in the pedagogical interventions, but since some PVs have more than one sense (literal and metaphorical; back out of a driveway and back out of a contract), some PVs were used more than once, resulting in the 50 items. The items on this test were collected from the BYU corpus (https://www.english-corpora.org/coca/) and presented to the learners in two different ways, using (1) gap-fill sentences (30 items), where the learners were provided the first letter for the two words in the PV (e.g., However, when long term marriage relationships $\mathrm{b}$ , the children will suffer a lot [end a relationship]) and (2) standard multiple-choice items (20 items). These different styles of test formatting have been used in previous PV research (Garnier \& Schmitt, 2016; Liao \& Fukuya, 2004), and therefore, the author designed a test utilizing both these styles in order to get a broader view of the participants' comprehension level of PVs.

As for the teaching interventions, each group was presented the same set of PVs in the same order but differed in their presentation approach. For example, the L1 translation group was presented the PVs accompanied by Japanese translations (see Figure 2); the cognitive image group was presented the PVs accompanied by simple diagrams/images that highlighted the meaning of them (see Figure 3); and the enactment group was presented the PVs, first with a slide that described the meanings of the PVs and then a video of the student(s) enacting the meaning of them using mimes, gestures, or a very short situational skit (see Figure 4).
Figure 2

Example From a Powerpoint Slide for the L1 Translation Group

\section{Break out}

- Start suddenly, especially undesirable things like war, disease, fire, including things of physical discomfort: sweat, rash, etc.

- Escape from a place of confinement (prison, cell, cage, etc.)

急に起こる・発生する・勃発する・発疹が出る・汗が 吹き出る

\section{>〈刑務所から〉脱出する・脱する}

Figure 3

Example From a Powerpoint Slide for the Cognitive Image Group

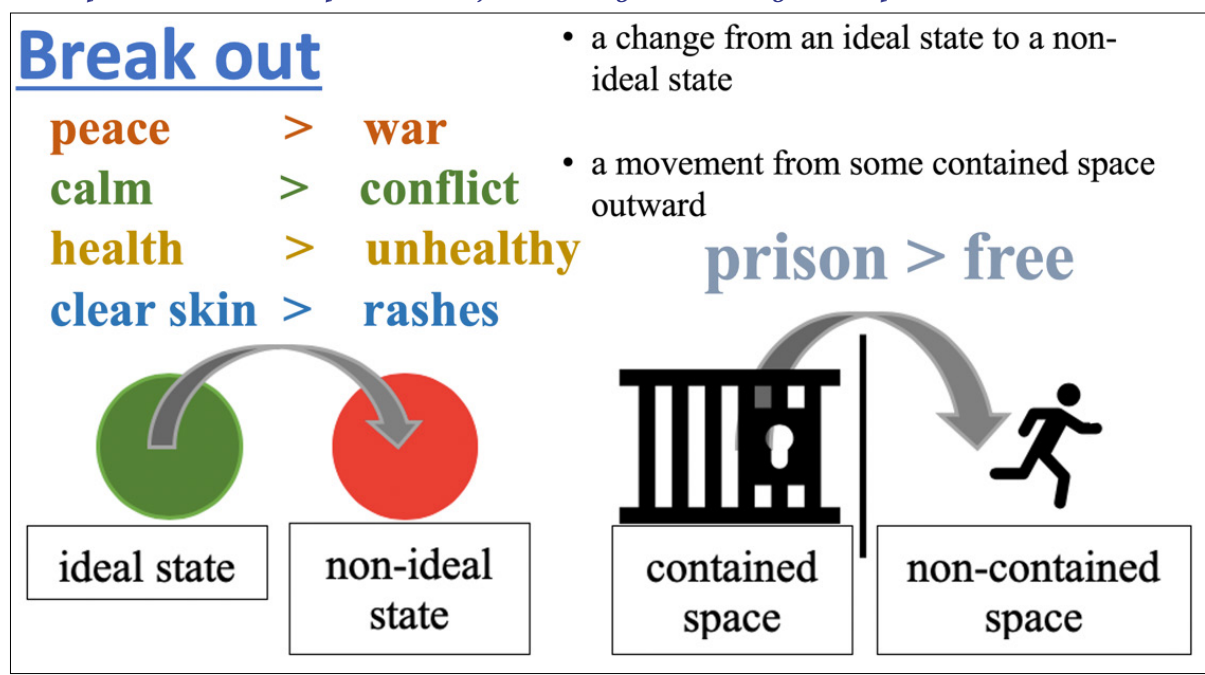




\section{JALT2020}

COMMUNITIES OF

\section{Figure 4}

Example from a screenshot of a video clip for the enactment group (The student research assistant provided the author permission to use this image)

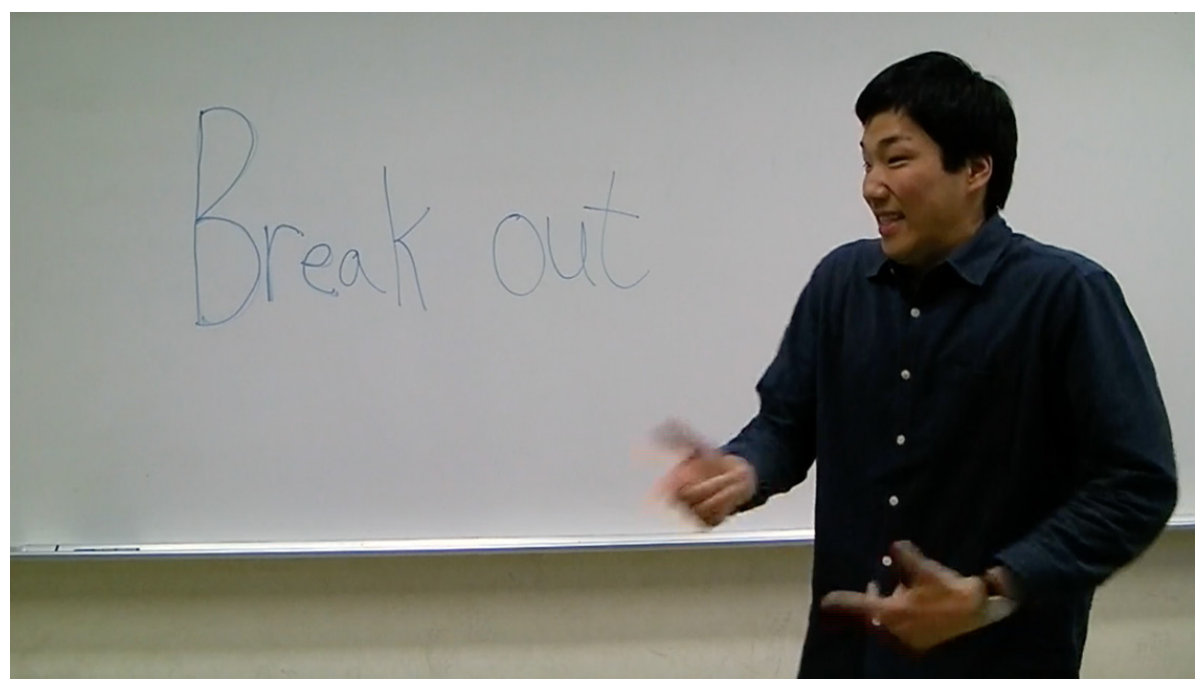

\section{Procedure}

During week 2 , students took the 50 -item pre-PV test. This was followed by 2 weeks of 20-minute teaching interventions where each group was presented the same set of PVs using the above three different conditions for a total of 40 minutes. Then in week 6 , students took a post- PV test, which was identical to the pre-PV test. In short, each group was exposed to the same set of $29 \mathrm{PVs}$ for the same amount of time in the way of a pedagogical intervention at the start of the class, the only difference being the method of teaching them.

\section{Results and Discussion}

Results

First, descriptive statistics of the pretest $(M=18.33, S D=5.17)$ and posttest $(M=$ $26.03, S D=6.65, M$ difference $=+7.70, S D=5.74)$ shows that students, on average, improved their PV knowledge through the pedagogical interventions. Secondly, in order to analyze the significance of this increase in the posttest scores, a paired samples $t$-test was performed (see Table 1). Based on this analysis, there was a statistically significant gain between student pre- and post-PV test scores $t(79)=12.00, p=.000$ with a very large effect size $(d=1.34)$. This indicates that the participants in this study, as a single group, significantly improved their test scores, which answers RQ1.

Table 1

A Paired Samples t-Test between the Pre and Post-PV Tests for all Participants

\begin{tabular}{|c|c|c|c|c|c|c|c|c|}
\hline & \multirow[b]{2}{*}{$\mathrm{M}$} & \multirow[b]{2}{*}{ SD } & \multicolumn{3}{|c|}{$\begin{array}{lc}95 \% \text { Confidence Interval } \\
\text { Std. Error } \quad \text { of the Difference }\end{array}$} & \multirow[b]{2}{*}{$\mathrm{t}$} & \multirow[b]{2}{*}{$\mathrm{df}$} & \multirow[b]{2}{*}{ Sig. } \\
\hline & & & Mean & Lower & Upper & & & \\
\hline $\begin{array}{l}\text { Pre-PV Test } \\
\text { Post-PV Test }\end{array}$ & -7.700 & 5.738 & 0.641 & -8.977 & -6.423 & -12.003 & 79 & .000 \\
\hline
\end{tabular}

Note. Very large effect size (Cohen's $d=1.34$ )

To answer RQ2 that asked if learners' scores from one group significantly improved more than the other groups, an ANCOVA was performed. Results show that there were significant differences with a large effect size in posttest scores between subjects in the three teaching approaches used in this study, $F(2,76)=10.158, p<.001, \eta_{\mathrm{p}}^{2}=.211$ (see Table 2 ).

Table 2

Results of ANCOVA for Between-Subjects Effects of Different Teaching Approaches

\begin{tabular}{lrrrrcc}
\hline Sources & \multicolumn{1}{c}{$S S$} & $d f$ & \multicolumn{1}{c}{$M S$} & \multicolumn{1}{c}{$F$} & $p$ & $\eta_{\mathrm{p}}{ }^{2}$ \\
\hline Corrected Model & 1582.880 & 3 & 527.627 & 20.939 & $<.001$ & .453 \\
Intercept & 1448.424 & 1 & 1448.424 & 57.481 & $<.001$ & .431 \\
Pretest & 344.248 & 1 & 344.248 & 13.662 & $<.001$ & .152 \\
Teaching Approach & 511.942 & 2 & 255.971 & 10.158 & $<.001$ & .211 \\
Error & 1915.070 & 76 & 25.198 & & & \\
Total & 57682.000 & 80 & & & & \\
Corrected Total & 3497.950 & 79 & & & & \\
\hline
\end{tabular}

Note. Dependent variable: Posttest scores 
In order to examine which specific posttest scores for the different teaching approaches differed, a post hoc comparison using ANCOVA with Bonferroni indicated that the mean score for the enactment group $(M D=6.781, S D=1.534, \mathrm{p}<.000)$ was significantly different than the $\mathrm{L} 1$ translation group, but not the cognitive image group $(M D=1.929, S D=1.381)$. In addition, the mean score for the cognitive image group $(M D$ $=4.852, S D=1.479, p=.005$ ) was significantly different than the L1 translation group. Taken together, these results suggest that the enactment and cognitive image groups outperformed the L1 translation group on the PV posttest. However, the cognitive image and enactment groups did not show any difference.

Table 3

Results of the Post Hoc Comparison Using ANCOVA Measure: Posttest

\begin{tabular}{|c|c|c|c|c|c|c|}
\hline \multirow{2}{*}{$\begin{array}{l}\text { Teaching } \\
\text { Approaches (J) }\end{array}$} & \multirow{2}{*}{$\begin{array}{c}\text { Teaching } \\
\text { Approach }(\mathrm{J})\end{array}$} & \multirow{2}{*}{$\begin{array}{c}\text { Mean } \\
\text { Difference } \\
(\mathrm{I}-\mathrm{J})\end{array}$} & \multirow{2}{*}{$\begin{array}{l}\text { Std. } \\
\text { Error }\end{array}$} & \multirow[b]{2}{*}{ Sig. $^{a}$} & \multicolumn{2}{|c|}{$\begin{array}{l}\text { 95\% Confidence } \\
\text { Interval for } \\
\text { Difference }^{\mathrm{a}}\end{array}$} \\
\hline & & & & & Lower & Higher \\
\hline \multirow[t]{2}{*}{ L1 translation } & Cognitive image & $-4.852 *$ & 1.479 & .005 & -8.471 & -1.232 \\
\hline & Enactment & $-6.781 *$ & 1.534 & .000 & -10.536 & -3.026 \\
\hline \multirow[t]{2}{*}{ Cognitive image } & L1 translation & $4.852 *$ & 1.479 & .005 & 1.232 & 8.471 \\
\hline & Enactment & -1.929 & 1.381 & .500 & -5.311 & 1.452 \\
\hline \multirow[t]{2}{*}{ Enactment } & L1 translation & $6.781 *$ & 1.534 & .000 & 3.026 & 10.536 \\
\hline & Cognitive image & 1.929 & 1.381 & .500 & -1.452 & 5.311 \\
\hline
\end{tabular}

Note. ${ }^{\text {a }}$ Adjustment for multiple comparisons: Bonferroni.

* The mean difference is significant at the .05 level

\section{Discussion}

This study analyzed different approaches to teaching PVs. Several relevant outcomes can be observed from the results and are applicable for language teachers. First, from observing the pretest scores of all three groups, even advanced level students lack PV knowledge, as indicated by the cumulative average score of all three groups (only $37 \%$ on the 50-item pre PV test). This overall lack of knowledge and results from this study suggest the need for a more experiential pedagogy for teaching PVs, which focuses on using images, conceptual structures, and the body. This is a move away from common PV textbooks that organize PVs based on the particle (e.g., in, off, on, etc.), concepts (e.g., time, memory, etc.) or the world around us (e.g., nature, weather, etc.) (see McCarthy \& O'Dell, 2007) or through grammatical constructions (passive PVs, separable and nonseparable PVs) (see Hart, 2009). Secondly, this study shows that short pedagogical interventions in the format of mini-lessons have positive effects on learning PVs. Moreover, all three teaching approaches enhanced their ability to recall the PVs on a posttest. Nonetheless, using imagery based on the image schema of the PV or watching an individual enact the meaning of the PV showed the greatest benefits. Yet, the results from this study should be taken with some caution. For example, there is likely no perfect approach and even those who have researched and found positive results using a cognitive linguistic approach to teaching them have also noted that not all PVs fit the cognitive model (Condon, 2008). It should be noted that not all PVs fit the enactment model. Thus, PVs should be categorized based on ease of communicating the meaning to the learner and in some cases, this is likely through pointing out the cognitive motivation of it (use up, completion; show up, more visible) and at other times enacting the meaning through gesture or pantomime (back up, physically pushing someone's back in order to keep them in an upright position to show your support) and possibly other times using language to convey the meaning.

Finally, it should be noted that there are several limitations to this study. First, it would have been informative to include a delayed posttest in order to evaluate retention of the target PVs over a longer extended period of time. Also, the enactment group only watched videos of students miming, enacting, and/or gesturing the meaning of these PVs, it would be more beneficial, as indicated by previous research (Morett, 2014), to have the students themselves perform these enactments. In addition, this study only had two teaching interventions, it would be preferable to increase this number to four to six along with reducing the number of PVs taught during each intervention. Lastly, this was a small study with a limited sample size, so caution should be taken when interpreting these results.

\section{Conclusion}

In conclusion, as researchers in the past have noted the ubiquity of PVs in the English language (Celce-Murcia \& Larsen-Freeman, 1999, p. 425) with some estimating that there is one PV in every 150 words of English (Gardner \& Davies, 2007), it is important to continue exploring more effective approaches to teaching them. The sheer number of PVs, along with them often being polysemous and highly metaphorical (Gardner 
\& Davies, 2007), can have an overwhelming effect on trying to teach them, yet their importance within the language cannot be underestimated and continuing this line of research is fruitful for both language instructors and cognitive linguists.

\section{Bio Data}

Brian J. Birdsell received a Ph.D. in Applied Linguistics from the University of Birmingham, UK and currently is an Associate Professor in the Center for Liberal Arts Development and Practices at Hirosaki University. His research interests include metaphor, embodied cognition, creativity, and CLIL. <brian@hirosaki-u.ac.jp>

\section{Acknowledgments}

This work was supported by JSPS KAKENHI Grant Number JP19K13256.

\section{References}

Anderson, M. L. (2014). After phrenology: Neural reuse and the interactive brain. MIT Press. Atkinson, D. (2010). Extended, embodied cognition and second language acquisition. Applied Linguistics, 31(5), 599-622. https://doi.org/10.1093/applin/amq009

Barros-Loscertales, A., González, J., Pulvermüller, F., Ventura-Campos, N., Bustamante, J. C., Birdsell, B. J. (2015). Action Learning: Putting the Mind Back into the Body in SLA. English Lingual Journal, 1(2), 36-56.

Birdsell, B. J. (2020). Language and Movement: Embodied Learning for Foreign Language Education. Journal of Liberal Arts Development and Practices, 4, 15-25.

Barsalou, L. W. (2008). Grounded cognition. Annual Review of Psychology, 59, 617-645. https://doi. org/10.1146/annurev.psych.59.103006.093639

Buccino, G., Binkofski, F., Fink, G. R., Fadiga, L., Fogassi, L., Gallese, V., ... \& Freund, H. J. (2001). Action observation activates premotor and parietal areas in a somatotopic manner: an fMRI study. European Journal of Neuroscience, 13(2), 400-404. https://doi.org/10.1111/j.14609568.2001.01385.x

Celce-Murcia, M., \& Larsen-Freeman, D. (1999). The grammar book: An ESL/EFL teacher's course (2nd ed.). Boston: Heinle \& Heinle.

Condon, N. (2008). How cognitive linguistic motivations influence the learning of phrasal verbs. In F. Boers \& S. Lindstromberg (Eds.), Applications of Cognitive Linguistics, 6, (pp. 133-158). Berlin: Mouton de Gruyter.
Csábi, S. (2004). A cognitive linguistic view of polysemy in English and its implications for teaching. In M. Achard \& S. Niemeier (Eds.), Cognitive linguistics, second language acquisition, and foreign language teaching, (pp. 233-256). Berlin: Mouton de Gruyter.

Dove, G. (2011). On the need for embodied and dis-embodied cognition. Frontiers in Psychology, 1, 242. https://doi.org/10.3389/fpsyg.2010.00242

Gallese, V., \& Lakoff, G. (2005). The brain's concepts: The role of the sensory-motor system in conceptual knowledge. Cognitive Neuropsychology, 22(3-4), 455-479. https://doi. org/10.1080/02643290442000310

Gardner, D., \& Davies, M. (2007). Pointing out frequent phrasal verbs: A corpus-based analysis. TESOL Quarterly, 41(2), 339-359. https://doi.org/10.1002/j.1545-7249.2007.tb00062.x

Garnier, M., \& Schmitt, N. (2015). The PHaVE List: A pedagogical list of phrasal verbs and their most frequent meaning senses. Language Teaching Research, 19(6), 645-666. https://doi. org $/ 10.1177 / 1362168814559798$

Garnier, M., \& Schmitt, N. (2016). Picking up polysemous phrasal verbs: How many do learners know and what facilitates this knowledge?. System, 59, 29-44. https://doi.org/10.1016/j. system.2016.04.004

Gibbs, R. W. Jr. (2005). Embodiment and cognitive science. Cambridge University Press.

Glenberg, A. M., Witt, J. K., \& Metcalfe, J. (2013). From the revolution to embodiment: 25 years of cognitive psychology. Perspectives on psychological science, 8(5), 573-585. https://doi. org/10.1177/1745691613498098

González, J., Barros-Loscertales, A., Pulvermüller, F., Meseguer, V., Sanjuán, A., Belloch, V., \& Ávila, C. (2006). Reading cinnamon activates olfactory brain regions. Neuroimage, 32(2), 906-912. https://doi.org/10.1016/j.neuroimage.2006.03.037

Hart, C. W. (2009). Ultimate phrasal verb book (2nd ed). Barron's Educational Series

Hauk, O., Johnsrude, I., and Pulvermüller, F. (2004). Somatotopic representation of action words in human motor and premotor cortex. Neuron, 41, 301-307. https://doi.org/10.1016/S08966273(03)00838-9

Holme, R. (2009). Cognitive linguistics and language teaching. Basingstoke: Palgrave Macmillan. Jahangard, A. (2007). Evaluation of the EFL materials taught at Iranian high schools. The Asian EFL Journal, 9(2), 130-150.

Jamrozik, A., McQuire, M., Cardillo, E. R., \& Chatterjee, A. (2016). Metaphor: Bridging embodiment to abstraction. Psychonomic bulletin \& review, 23(4), 1080-1089. https://doi.org/10.3758/s13423015-0861-0

Johnson, M. (1987). The body in the mind: The bodily basis of meaning, imagination, and reason. Chicago: The University of Chicago Press.

Lakoff, G. (1987). Women, fire, and dangerous things. Chicago: Chicago University Press. 
Liao, Y., \& Fukuya, Y. J. (2004). Avoidance of phrasal verbs: The case of Chinese learners of English. Language learning, 54(2), 193-226. https://doi.org/10.1111/j.1467-9922.2004.00254.x

Lindstromberg, S., \& Boers, F. (2005). From movement to metaphor with manner-of-movement verbs. Applied linguistics, 26(2), 241-261. https://doi.org/10.1093/applin/ami002

Macedonia, M., \& Klimesch, W. (2014). Long-term effects of gestures on memory for foreign language words trained in the classroom. Mind, Brain, and Education, 8(2), 74-88. https://doi. org/10.1111/mbe.12047

Macedonia, M., \& Knösche, T. R. (2011). Body in mind: How gestures empower foreign language learning. Mind, Brain, and Education, 5(4), 196-211. https://doi.org/10.1111/j.1751228X.2011.01129.x

McCarthy, M., \& O’Dell, F. (2007). English phrasal verbs in use: Advanced. Cambridge University Press.

Morett, L. M. (2014). When hands speak louder than words: The role of gesture in the communication, encoding, and recall of words in a novel second language. The Modern Language Journal, 98(3), 834-853. https://doi.org/10.1111/modl.12125

Omaggio, A. C. (1979). Pictures and second language comprehension: Do they help?. Foreign Language Annals, 12(2), 107-116. https://doi.org/10.1111/j.1944-9720.1979.tb00153.x

Rudzka-Ostyn, B. (2003). Word power: Phrasal verbs and compounds: A cognitive approach. Walter de Gruyter.

Sakreida, K., Scorolli, C., Menz, M. M., Heim, S., Borghi, A. M., \& Binkofski, F. (2013). Are abstract action words embodied? An fMRI investigation at the interface between language and motor cognition. Frontiers in Human Neuroscience, 7, 125. https://doi.org/10.3389/fnhum.2013.00125

Siyanova, A., \& Schmitt, N. (2007). Native and nonnative use of multi-word vs. one-word verbs. International Review of Applied Linguistics in Language Teaching, 45(2), 119-139. https://doi. org/10.1515/IRAL.2007.005

Skulmowski, A., \& Rey, G. D. (2018). Embodied learning: introducing a taxonomy based on bodily engagement and task integration. Cognitive research: principles and implications, 3(1), 6. https:// doi.org/10.1186/s41235-018-0092-9

Tyler, A., \& Evans, V. (2003). The semantics of English prepositions: spatial scenes, embodied meaning and cognition. Cambridge: Cambridge University Press.

Vukovic, N., and Shtyrov, Y. (2014). Cortical motor systems are involved in second-language comprehension: evidence from rapid mu-rhythm desynchronisation. Neuroimage, 102, 695-703 https://doi.org/10.1016/j.neuroimage.2014.08.039

White, B. J. (2012). A conceptual approach to the instruction of phrasal verbs. The Modern Language Journal, 96(3), 419-438. https://doi.org/10.1111/j.1540-4781.2012.01365.x
Yasuda, S. (2010). Learning phrasal verbs through conceptual metaphors: A case of Japanese EFL learners. TESOL Quarterly, 44(2), 250-273. 